\title{
PERAN KPJKS DALAM LEGISLASI FATWA DSN-MUI DI BIDANG REGULASI KEUANGAN SYARIAH ${ }^{1}$
}

\author{
Khotibul Umam, Vina Berliana Kimberly* \\ Fakultas Hukum Universitas Gadjah Mada \\ J1. Sosio Yustisia Bulaksumur No.1, Karang Malang, Caturtunggal, Kec. Depok, Kabupaten \\ Sleman, Daerah Istimewa Yogyakarta 55281 \\ vina.berliana.k@mail.ugm.ac.id
}

\begin{abstract}
This research aims Committee Development Services Finance Sharia (KPJKS) role within interpretation and harmonization of Fatwa of DSN-MUI for giving recommendation in formulating POJK in Islamic finance sector and principle of law which is used as a framework of role realization. Normative research method did by statute and conceptual approach. The data is using analysis qualitative. The result of this research: (1) KPJKS role within interpretation and harmonization of Fatwa of DSN-MUI in formulating of POJK in Islamic finance sector i.e giving recommendation for OJK; (2) The law principle which is used as a framework in role realization for producing recommendation is maslahat principle.
\end{abstract}

Keywords: Interpretation; Harmonization; Recommendation.

\begin{abstract}
Abstrak
Penelitian ini bertujuan menganalisis peran Komite Pengembangan Jasa Keuangan Syariah dalam interpretasi dan harmonisasi fatwa Dewan Syariah Nasional-Majelis Ulama Indonesia (DSN-MUI) guna memberikan rekomendasi bagi pembentukan Peraturan Otoritas Jasa Keuangan (POJK) di bidang keuangan syariah, serta prinsip hukum yang dijadikan sebagai dasar bagi realisasi peran dimaksud. Penelitian hukum normatif ini dilakukan dengan menggunakan pendekatan peraturan perundang-undangan dan pendekatan konsep. Analisis data dilakukan secara kualitatif. Hasil penelitian menunjukkan: (1) Peran KPJKS dalam melakukan interpretasi dan harmonisasi fatwa DSN-MUI bagi pembentukan POJK di bidang keuangan syariah, yakni memberikan rekomendasi bagi OJK; dan (2) Prinsip hukum yang dijadikan sebagai dasar bagi realisasi peran dimaksud guna menghasilkan rekomendasi, yakni prinsip kemaslahatan.
\end{abstract}

Kata Kunci: Interpretasi; Harmonisasi; Rekomendasi.

\footnotetext{
${ }^{1}$ Merupakan artikel hasil penelitian dari Program Penelitian Hibah Doktor Tahun 2019 pada Fakultas Hukum Universitas Gadjah Mada melalui Unit Riset dan Publikasi.
} 


\section{A. Pendahuluan}

Pasca dikeluarkannya Undang-Undang Nomor 21 Tahun 2011 tentang Otoritas Jasa Keuangan (selanjutnya disebut UU OJK), dalam Pasal 55 maka secara bertahap terhadap pengaturan dan pengawasannya sebagian dialihkan ke OJK sebagai lembaga yang mengatur, mengawasi, dan melindungi sektor jasa keuangan. Peralihan fungsi, tugas, dan wewenang pengaturan dan pengawasan kegiatan jasa keuangan di sektor Pasar Modal, Perasuransian, Dana Pensiun, Lembaga Pembiayaan, dan Lembaga Jasa Keuangan Lainnya dari Menteri Keuangan dan Badan Pengawas Pasar Modal ke OJK dilakukan per 31 Desember 2012, sedangkan peralihan fungsi, tugas, dan wewenang pengaturan dan pengawasan kegiatan jasa keuangan di sektor Perbankan beralih dari Bank Indonesia ke OJK sejak 31 Desember 2013. Peralihan sebagaimana dimaksud tidak secara keseluruhan, menurut Pasal 7 UU OJK hanya di ranah microprudential.

Undang-Undang Nomor 21 Tahun 2008 tentang Perbankan Syariah (selanjutnya disebut UUPS) melalui Pasal 26 ayat (4) mengamanahkan dibentuknya Komite Perbankan Syariah (KPS), yakni dalam rangka penyusunan Peraturan Bank Indonesia (PBI). Tugas, fungsi, dan wewenang KPS secara konkrit tertuang PBI No. 10/32/PBI/2008 tentang Komite Perbankan Syariah. Pasca beralihnya fungsi pengaturan di ranah microprudential dari Bank Indonesia ke OJK sejak 31 Desember 2013, berdasarkan laporan perkembangan keuangan syariah 2013 yang diterbitkan OJK, tugas KPS dialihkan kepada OJK yang mana diformulasikan dalam bentuk Komite Pengembangan Jasa Keuangan Syariah (KPJKS) OJK.

Teori hukum yang mendasari penelitian ini adalah teori utilitarian dan teori kemaslahatan. Menurut Jeremy Bentham, hukum menurut teori utilitarian dibentuk agar memberikan kebahagiaan/kemanfaatan yang mewujudkan kebahagiaan bagi setiap orang (Mertokusumo, 2003). Kebahagiaan/kemanfaatan ini tidak hanya diberikan tetapi perlu untuk dijamin bahwa kebahagiaan sebanyak-banyaknya akan dinikmati oleh orang sebanyak-banyaknya pula (Mas, 2004).

Teori maslahah adalah sebuah teori dalam Hukum Islam yang menghendaki bahwa diturunkannya hukum/syariah sebagai dasar agar tercapainya kebahagiaan hidup manusia tidak hanya di dunia melainkan juga di akhirat yang dilakukan dengan cara mengambil segala hal yang bermanfaat dan mencegah atau menghilangkan hal-hal yang bersifat mudharat (tidak bermanfaat) (Ali, 2000). Najm al-Din al-Tufi dalam "Maqasid alShari'ah al-Islamiyyah" karangan Al-Tahrir ibn Ashur, mendefinisikan maslahah adalah sesuatu yang dapat mewujudkan tujuan yang dihendaki oleh Legislator (Auda, 2007).

Berdasarkan penelusuran, penelitian tentang transformasi fatwa DSN-MUI ke dalam regulasi keuangan syariah memang sudah beberapa kali dilakukan. Beberapa di antaranya adalah "Positivisasi Fatwa DSNMUI tentang Mudarabah dalam Regulasi Otoritas Jasa Keuangan” (Alfarouq, 2018), "Pola dan Urgensi Positivisasi Fatwa-fatwa DSN-MUI Tentang Perbankan Syariah di Indonesia" (Fauzan, 2016), dan "Legislasi Fikih Ekonomi Perbankan: Sinkronisasi Peran DSN-MUI dan Komite Perbankan Syariah" (Umam, 2012). Sekalipun ketiga penelitian tersebut membahas tentang transformasi Fatwa DSN-MUI ke dalam regulasi keuangan syariah, ketiga penelitian tersebut berfokus pada fungsi Komite Pengembangan Syariah. Hal baru yang ada dalam penelitian ini adalah penelitian tidak menitikberatkan pembahasan pada Komite Pengembangan Syariah melainkan kepada fungsi KPJKS yang merupakan kelanjutan dari KPS sesuai amanat peraturan perundang-undangan dalam positivisasi Fatwa DSN-MUI ke dalam regulasi di Indonesia.

Rekomendasi sebagai produk yang dihasilkan oleh KPJKS secara konseptual adalah tidak mengikat OJK, sehingga perlu diketahui peran yang dimiliki KPJKS dan prinsip hukum apa saja yang dapat dijadikan 
dasar dalam pelaksanaan peran tersebut guna memperkuat perannya di ranah keuangan syariah. Adanya isu hukum sebagaimana dimaksud memunculkan permasalahan hukum, yakni: (1) Bagaimana peran KPJKS dalam melakukan interpretasi dan harmonisasi fatwa DSN-MUI bagi pembentukan POJK di bidang keuangan syariah?; dan (2) Prinsip hukum apa saja yang dapat dijadikan sebagai dasar bagi realisasi peran dimaksud guna menghasilkan rekomendasi yang kuat dan kompatibel bagi praktik lembaga keuangan syariah, namun tetap sesuai dengan prinsip syariah?

\section{B. Metode Penelitian}

Penelitian ini merupakan penelitian yang bersifat deskriptif analitis yang memberikan gambaran analitis tentang peran KPJKS dalam melakukan interpretasi dan harmonisasi fatwa DSN-MUI guna memberikan rekomendasi bagi pembentukan POJK di bidang keuangan syariah dan gambaran tentang prinsip hukum yang dapat dijadikan sebagai dasar bagi realisasi peran dimaksud guna menghasilkan rekomendasi yang kuat dan kompatibel bagi praktik lembaga keuangan syariah, namun tetap sesuai dengan prinsip syariah.

Berdasarkan cara pendekatannya, penelitian ini merupakan penelitian yuridis normatif, yaitu penelitian yang didasarkan pada penelitian kepustakaan guna memperoleh data sekunder di bidang hukum (Soekanto, 1986), khususnya pendekatan perundang-undangan (statute approach) dan pendekatan konseptual (conceptual approach) (Marzuki, 2005). Analisis dilakukan secara kualitatif. Metode kualitatif merupakan tata cara penelitian yang menghasilkan data deskriptif-analitis (Soekanto, 1986).

\section{Hasil Penelitian dan Pembahasan}

1. Peran KPJKS dalam Melakukan Interpretasi dan Harmonisasi Fatwa DSN-MUI bagi Pembentukan Regulasi di Bidang Keuangan Syariah
KPJKS merupakan komite yang berada di Departemen Perbankan Syariah OJK dan merupakan transformasi dari KPS yang awalnya berada di dalam Departemen Perbankan Syariah Bank Indonesia. Kata kunci utama yang menunjukkan adanya peran (role) adalah interpretasi dan harmonisasi terhadap fatwa sebelum materi dalam fatwa menjadi bahan bagi penyusunan regulasi di bidang keuangan syariah. Guna membahas sub bab ini, Peneliti susun ke dalam 3 (tiga) pokok bahasan, yakni:

Pertama, substansi fatwa DSN-MUI berkaitan dengan Perbankan Syariah, Pasar Modal Syariah dan Industri Keuangan NonBank Syariah. Keberadaan fatwa diakui dan berlaku bagi praktik di ketiga Lembaga Jasa Keuangan Syariah tersebut, yakni ditandai dengan adanya terminologi "Prinsip Syariah" dalam Pasal 1 angka 12 UUPS. Pasal 26 undang-undang a quo memberikan ketentuan bahwa kegiatan usaha dan/atau produk dan jasa syariah, wajib tunduk kepada Prinsip Syariah sebagaimana difatwakan oleh Majelis Ulama Indonesia. Fatwa sebagaimana dimaksud dituangkan dalam Peraturan Bank Indonesia (kini POJK) dan dalam rangka penyusunan Peraturan Bank Indonesia, Bank Indonesia membentuk komite perbankan syariah (kini di bawah OJK berubah dari KPS menjadi KPJKS).

Kedua, arti penting, tugas dan fungsi KPJKS dalam Pembentukan regulasi di bidang keuangan syariah. Berdasarkan UU OJK, Dewan Komisioner OJK menetapkan Peraturan Dewan Komisioner OJK tentang pembentukan Komite Pengembangan Jasa Keuangan Syariah (KPJKS). Menurut Siaran PERS SP-20/DKNS/OJK/8/2014, KPJKS menjadi penting untuk dibentuk karena Industri Jasa Keuangan Syariah memerlukan dukungan dari pihak-pihak terkait dalam rangka pengembangan dan penyempurnaan regulasi dan sistem pengawasan yang efektif, infrastruktur keuangan yang lengkap dan berbagai kegiatan edukasi, pengembangan pasar dan perlindungan konsumen yang komprensif. 
Pada bagian ini Peneliti memfokuskan pada aspek pengaturan, yakni pembentukan regulasi di bidang keuangan syariah. KPJKS kaitannya dengan regulasi keuangan syariah berperan dalam melakukan interpretasi atau harmonisasi terhadap fatwa sebelum dijadikan materi dalam regulasi keuangan syariah dalam bentuk POJK atau SEOJK. Interpretasi hukum merupakan salah satu metode penemuan hukum yang memberi penjelasan gamblang mengenai teks peraturan perundang-undangan agar ruang lingkup kaidah hukum dapat diterapkan sehubungan dengan peristiwa tertentu (Mertokusumo, 2003). Guna menafsirkan teks hukum, Hukum Islam juga menyediakan aneka metode berijtihad baik berupa metode interpretasi maupun metode argumentasi. Teks al-Qur'an maupun asSunah dapat ditafsirkan antara lain secara historis, yakni dengan memahamai asbabun nuzul (al-Qur'an) dan asbabul wurud (alHadis), ditafsirkan secara teleologis atau mendasarkan pada tujuan, yakni dengan mendasarkan pada maqashid syariah dan hukum Islam juga menyediakan kerangka argumentasi berupa metode qiyas atau yang dapat diartikan sebagai analogi (Kusroni, 2019). Harmonisasi dilakukan guna mendapatkan sinkronisasi dan koherensi antara aturan yang akan dibentuk dengan aturan-aturan lain yang sudah ada, sehingga dengan dibentuknya aturan baru dalam hal ini POJK/SEOJK yang mendasarkan pada fatwa in line dengan aturan-aturan lain dan sekaligus praktik di lembaga keuangan.

Beberapa hal yang sudah dilaksanakan sejak tahun 2014 hingga tahun 2018 guna mendapatkan gambaran mengenai peran KPJKS secara nyata dalam pengembangan industri keuangan syariah. Data Peneliti peroleh dari Laporan Perkembangan Keuangan Syariah dari tahun 2014 hingga 2018, yakni sebagai berikut:

Pertama, bahwa OJK telah melakukan berbagai upaya agar industri jasa keuangan syariah senantiasa dapat tumbuh dengan baik, antara lain dengan membentuk dan mendukung bekerjanya Komite Pengembangan Jasa Keuangan Syariah
(KPJKS) di mana anggotanya berasal dari internal OJK dan eksternal OJK seperti perwakilan kementerian dan lembaga negara maupun otoritas fatwa serta organisasi Islam. Pembentukan KPJKS ini bertujuan untuk sinkronisasi maupun integrasi kebijakan strategis dan operasional di bidang pengembangan jasa keuangan syariah serta implementasi fatwa Majelis Ulama Indonesia (MUI) ke dalam peraturan OJK. (Tim Penyusun Materi Pengembangan Keuangan Syariah 2014, 2014). KPJKS dalam pelaksanaan fungsi dan tugasnya didukung oleh Tim Kerja yang melaksanakan fungsi analisis dan pendalaman berbagai isu dan permasalahan pengembangan keuangan syariah nasional yang selanjutnya akan dipaparkan di dalam rapat KPJKS. Tim Kerja KPJKS terdiri dari pejabat OJK dari satuan kerja terkait pengawasan industri jasa keuangan syariah dan pihak eksternal dengan berbagai bidang keahlian yang berasal antara lain dari DSNMUI, tokoh ulama, akademisi, dan praktisi keuangan syariah.

Kedua, dalam rangka mendukung inovasi dan mempercepat adopsi produk secara industri dan sebagai tindak lanjut arahan Komite Pengembangan Jasa Keuangan Syariah (KPJKS), pada tahun 2015 peran Working Group Perbankan Syariah (WGPS) diaktifkan kembali sebagai forum yang turut mendukung program kerja OJK.(Tim Penyusun Materi Pengembangan Keuangan Syariah 2015, 2015). Di mana pada tahun 2015, revitalisasi forum WGPS tersebut tidak hanya melibatkan DSN-MUI, Dewan Standar Akuntansi Syariah (DSAS) IAI dan Asosiasi/Pelaku Industri Jasa Keuangan Syariah namun juga saat ini melibatkan Mahkamah Agung (MA). Kegiatan yang dilakukan dalam rangka pengembangan produk melalui revitalisasi dan reaktivasi WGPS, selain rapat teknis adalah rapat pleno WGPS yang mengundang pimpinan OJK, DSN-MUI, MA RI dan DSAS IAI serta pelaku industri (asosiasi) guna mengesahkan rekomendasi terkait draft fatwa. Pada tahun 2015 Forum WGPS telah melakukan pembahasan dan mengeluarkan 
rekomendasi fatwa yaitu Fatwa Transaksi Lindung Nilai Syariah (al-Tahawwut alIslami/Islamic Hedging) atas Nilai Tukar dan Fatwa Sertifikat Deposito Syariah/Islamic Negotiable Certificate of Deposit (NCD Syariah).

Ketiga, WGPS juga berpartisipasi dalam kegiatan bidang review kebijakan dan standar nasional WGPS merupakan forum untuk mendiskusikan dan mengesahkan rekomendasi draft fatwa yang dibutuhkan oleh industri perbankan syariah (Tim Penyusun Materi Pengembangan Keuangan Syariah 2016, 2016). Keanggotaan WGPS terdiri dari OJK, Dewan Syariah Nasional Majelis Ulama Indonesia (DSN-MUI), Dewan Standar Akuntansi Syariah Ikatan Akuntansi Indonesia (DSAS-IAI), dan Mahkamah Agung Republik Indonesia (MA-RI).

Keempat, pada tahun 2017 Forum WGPS membahas hal-hal sebagai berikut (Tim Penyusun Materi Pengembangan Keuangan Syariah 2017, 2017): Fatwa DSN MUI merupakan acuan bagi perbankan syariah dalam menjalankan operasionalnya serta acuan bagi Peradilan Agama dalam menangani perkara perdata Islam, khususnya perkara di bidang ekonomi syariah, sehingga perlu adanya pembahasan bersama dengan stakeholders terkait. Hal-hal yang dibahas adalah sebagai berikut: Akad jual-beli, Akad jual-beli murabahah, Akad syirkah, Akad mudharabah, Akad ijarah, Akad wakalah bil ujrah, Uang Elektronik Syariah, Penjaminan simpanan syariah oleh Lembaga Penjamin Simpanan dilaksanakan berdasarkan prinsip kafalah, Pembiayaan pribadi/personal financing syariah, dan Rancangan peraturan OJK tentang penerapan tata kelola dalam pemberian remunerasi bagi bank umum syariah dan unit usaha syariah (RPOJK Tata Kelola Remunerasi BUS UUS). Pembahasan dasar syariah remunerasi ini bertujuan untuk menciptakan disiplin pasar dan transparansi informasi mengenai pemberian remunerasi baik yang bersifat kualitatif maupun kuantitatif yang sesuai dengan prinsip syariah.
Kelima, pada tahun 2018 juga telah diselenggarakan WGPS yang terdiri dari perwakilan OJK, DSN-MUI, Badilag MA RI, DSAS-IAI, dan Bank Syariah membahas rancangan fatwa DSN-MUI untuk pengembangan produk perbankan syariah (Tim Penyusun Materi Pengembangan Keuangan Syariah 2018, 2018). Tahun 2018 kegiatan WGPS diselenggarakan di Jakarta dengan topik bahasan: opini syariah atas penyediaan jasa E-Money di perbankan syariah, perdagangan Sertifikat Deposito Syariah di pasar sekunder, pendalaman pasar keuangan syariah, serta penerapan fatwa tentang sekuritisasi asset di perbankan syariah.

Berdasarkan informasi resmi yang tertuang pada Laporan Perkembangan Keuangan Syariah dari tahun 2014 hingga 2018, terlihat bahwa terdapat forum multistakeholders guna membahas draft fatwa. OJK dan DSN-MUI menjadi lembaga kunci bagi pembentukan fatwa dan nantinya juga selalu berkoordinasi pada saat penyusunan regulasi di bidang keuangan syariah. Dengan mendasarkan pada multiperspektif antar lembaga yang terlibat dalam WGPS yang tidak hanya membahas perbankan syariah, maka diharapkan fatwa yang dihasilkan adalah harmonis terhadap praktik di Industri Keuangan Syariah. Apabila hal ini terjadi, maka proses penyusunan rekomendasi oleh KPJKS yang di dalamnya juga terdiri dari OJK, DSNMUI dan professional di bidang keuangan syariah akan lebih mudah. Koordinasi berlapis multistakeholders sejak penyusunan fatwa hingga penuangannya dalam regulasi di bidang keuangan syariah akan berdampak pada munculnya POJK atau SEOJK terkait dengan keuangan syariah yang sejalan dengan hukum Islam dan kompatibel terhadap praktik.

Ketiga, aturan dan prosedur transformasi fatwa ke dalam regulasi di bidang keuangan syariah. Peneliti telah kemukakan bahwa antara DSN-MUI dan OJK terjadi konsultasi timbal balik dalam proses penyusunan fatwa dan regulasi keuangan syariah guna memberikan jaminan 
pemenuhan prinsip syariah dalam pemberian produk maupun aktivitas Lembaga Jasa Keuangan Syariah.

Harmonisasi regulasi dan fatwa dilakukan melalui forum WGPS, artinya terjadi pembahasan multistakeholders guna menghasilkan produk hukum berupa regulasi, yakni berupa Peraturan Otoritas Jasa Keuangan. Pasal 1 angka 13 UU OJK memberikan pengertian teknis POJK sebagai peraturan tertulis yang ditetapkan oleh Dewan Komisioner, mengikat secara umum, dan diundangkan dalam Lembaran Negara Republik Indonesia. WGPS ini merupakan implementasi nyata diterapkannya teori kemaslahatan dalam transformasi fatwa DSN-MUI ke dalam regulasi keuangan syariah agar transformasi dan metode istinbat (penemuan hukum) yang dilakukan WGPS bukan sebuah upaya menghilangkan nash, melainkan untuk mencapai adanya sebuah kepastian hukum yang diwujudkan melalui adanya kemaslahatan. Hukum dasar bahwa kemaslahatan harus sesuai dengan nash (Zahrah, 2018) dapat diimplemetasikan dengan adanya sebuah hubungan timbal baik antara DSN-MUI dan OJK sebagai lembaga terpenting yang mengeluarkan regulasi di bidang keuangan syariah dan secara $e x$ officio perwakilan dari kedua lembaga tersebut ada dalam struktur KPJKS.

KPJKS yang merupakan sebuah komite yang ada di OJK sebagaimana KPS yang berada di bawah Bank Indonesia memiliki peran melakukan interpretasi dan harmonisasi fatwa yang hasilnya dituangkan dalam bentuk rekomendasi. Hingga saat ini Peneliti tidak menemukan aturan spesifik yang memberikan pengaturan terhadap KPJKS, sehingga pada bagian ini dengan mengingat KPJKS adalah kelanjutan dari KPS, Peneliti mendasarkan pada Peraturan Bank Indonesia Nomor 10/32/PBI/2008 tentang Komite Perbankan Syariah, untuk menggambarkan aturan dan prosedur transformasi fatwa ke dalam regulasi (Kalsum, 2018).

Dalam Pasal 1 angka 1 Peraturan Bank Indonesia Nomor 10/32/PBI/2008 disebutkan bahwa KPS, yang selanjutnya disebut Komite adalah forum yang beranggotakan para ahli di bidang syariah muamalah dan/atau ahli ekonomi, ahli keuangan, dan ahli perbankan, yang bertugas membantu Bank Indonesia dalam mengimplementasikan fatwa Majelis Ulama Indonesia menjadi ketentuan yang akan dituangkan ke dalam Peraturan Bank Indonesia. Kemudian dalam Pasal 1 angka 2 disebutkan bahwa Majelis Ulama Indonesia, yang selanjutnya disebut MUI adalah wadah atau majelis yang menghimpun para ulama, tokoh masyarakat (zuama) dan cendekiawan muslim Indonesia untuk menyatukan gerak dan langkah-langkah umat Islam Indonesia dalam mewujudkan cita-cita bersama, yang salah satu peran utamanya adalah sebagai pemberi fatwa.

Dalam menjalankan tugasnya, Komite dibantu oleh Sekretariat Komite yang salah satu tugasnya melaksanakan fungsi administrasi dan korespondensi Komite. Bank Indonesia menetapkan masa jabatan anggota Komite yang bertanggung jawab kepada Bank Indonesia ini adalah dua tahun dan dapat diperpanjang maksimal dua kali masa jabatan. Namun anggota dapat diberhentikan dari Komite karena alasanalasan tertentu (Pasal 15 dan Pasal 17 PBI No. 10/32/PBI/2008 tentang Komite Perbankan Syariah). Dalam praktik, kedudukan KPS adalah independen, namun secara administrasi dan keuangan dikoordinasikan oleh Direktorat Perbankan Syariah (DPbS) (Wawancara dengan Direktorat Pengaturan Perbankan Syariah, Bank Indonesia, 26 Desember 2010).

Rapat Komite diselenggarakan atas dasar usulan Bank Indonesia atau usulan Komite sendiri. Rapat Komite dinyatakan sah apabila memenuhi kuorum yaitu dihadiri oleh lebih dari 50\% keanggotaan Komite. Kemudian Pengambilan keputusan Rapat Komite dilakukan atas dasar musyawarah untuk mencapai mufakat (Pasal 19 dan Pasal 20 PBI No. 10/32/PBI/2008 tentang Komite Perbankan Syariah).

Rekomendasi Komite dimaksud tidak mengikat, dalam arti harus diikuti oleh DPbS. Hal ini terjadi karena dalam 
perspektif DPbS Bank Indonesia, pembuatan PBI terkait dengan produk bank syariah tidak semata-mata tergantung pada fatwa, melainkan ditentukan pula oleh tingkat risiko dan kehati-hatian sebuah produk ketika diimplementasikan dalam praktik (Umam, 2012). Secara mutatis mutandis, PBI a quo juga dapat diberikan sebagai landasan bagi KPJKS yang merupakan kelanjutan dari KPS. Kata kunci dalam PBI adalah rekomendasi, artinya hasil penelaahan KPS atau saat ini adalah KPJKS terhadap fatwa sebelum menjadi regulasi hanya sebatas memberikan rekomendasi sehingga kata akhir tetap berada pada Dewan Komisioner sebagai organ OJK yang berwenang membentuk POJK. Walaupun demikian kontrol terhadap POJK (SEOJK) mengenai keuangan syariah dapat terlaksana dengan baik, karena dalam praktiknya koordinasi timbal balik sejak pembentukan fatwa hingga regulasi senantiasa dilakukan terutama oleh OJK dan DSN-MUI.

Pemaparan tersebut menunjukkan bahwa adanya KPJKS untuk mentransformasikan fatwa DSN-MUI ke dalam regulasi adalah wujud untuk menciptakan adanya kemanfaatan atau utilitarian. Menurut Jeremy Bentham, kebahagiaan bagi sebanyak mungkin orang atau dalam istilah hukum Islam dikenal dengan maslahah ammah adalah inti dari terbentuknya sebuah hukum. Menurut Mohammad Daud Ali bahwa tujuan diturunkannya syariah (maqasid syariah) adalah untuk mencapai kebahagiaan dunia dan akhirat dengan cara menghilangkan mudharat dan mengambil manfaat (Ali, 2000). Eksistensi teori kemanfaatan ditunjukkan, antara lain dari: Pertama, diakuinya fatwa DSN-MUI dalam peraturanperaturan OJK, salah satunya dalam POJK No. 15/POJK.04/2015 tentang Penerapan Prinsip Syariah di Pasar Modal, yang dalam Pasal 1 angka 2 POJK a quo Prinsip Syariah di Pasar Modal didefinisikan sebagai prinsip hukum Islam dalam Kegiatan Syariah di Pasar Modal berdasarkan fatwa DSN-MUI. Kedua, dilakukannya interpretasi baik menggunakan metode hukum nasional maupun hukum Islam dalam perumusan rekomendasi penuangan fatwa ke dalam regulasi. Ketiga, dilakukannya harmonisasi peraturan agar tidak ada peraturan yang sama saling berseberangan atau saling tumpang tindih. Ketiga hal tersebut akan memudahkan praktisi, akademisi, maupun masyarakat dalam menyelesaikan persoalan yang ada terkait keuangan syariah dan sekaligus memberikan kemanfaatan bagi seluruh aspek dalam masyarakat karena tidak ada lembaga maupun peraturan yang saling bertentangan satu dengan lainnya.

\section{Prinsip Hukum yang Dapat Dijadikan sebagai Dasar bagi Realisasi Peran Dimaksud guna Menghasilkan Rekomendasi yang Kuat dan Kompatibel bagi Praktik Lembaga Keuangan Syariah, namun Tetap Sesuai dengan Prinsip Syariah}

Dalam mencari sumber hukum sebagai landasan sebuah fatwa, umat Islam dapat melakukan penalaran melalui istinbat. Akan tetapi, istinbat juga harus berpedoman pada Al-Quran dan Al-Hadist (Bahri, 2011). Metode istinbat yang lazim digunakan dalam hukum ekonomi islam di Indonesia adalah Ijma dan Qiyas. Kaidah fiqiyah juga memegang peran penting dalam proses istinbat hukum (Iqbal, 2018). Jumlah kaidah fikih sebenarnya ada ratusan, namun dari ratusan kaidah dapah disederhanakan menjadi lima kaidah utama yang disepakati oleh para ahli ushul fiqih (Hammam, 2017). Kelima kaidah tersebut, yaitu sebagai berikut:

\section{a. Segala Sesuatu Tergantung Tujuannya (al umur bi maqashidiha)}

Tujuan menjadi penting dalam kehidupan manusia. Hal ini dikarenakan setiap perbuatan yang dilakukan manusia sudah pasti memiliki tujuan. Menentukan sebuah tujuan merupakan naluri alami manusia (Zubair, 2017). Manusia dalam melakukan urusan dan muamalah juga didasarkan pada maksud tertentu (Munir Al-Qardhi dalam Syarh Al-Majallah yang dikutip dalam Zaidan, 2008). Salah satu contoh aplikasi kaidah 
ini adalah apabila seseorang menemukan anak yang hilang atau tersesat, kemudian anak tersebut meninggal dunia dalam perjalanan dikembalikan ke orang tuanya, maka seseorang tersebut tidak dapat dihukum (Zaidan, 2008).

\section{b. Keyakinan Tidak Dapat Dihilangkan oleh Kebimbangan (al-yaqin la yuzalu bi al-syakk)}

Al-yaqin (keyakinan) secara bahasa adalah kemantapan hati seseorang atas terjadi atau tidak terjadinya sesuatu, sedangkan asy-syakh (keraguan) adalah ketidakmantapan hati seseorang atas terjadi atau tidak terjadinya sesuatu (Zaidan, 2008). Kaidah ini dimaksudkan bahwa sebuah keyakinan tidak dapat dihilangkan karena keraguan yang datang, melainkan dapat dihilangkan dengan keyakinan yang sama (Zaidan, 2008). Salah satu contoh aplikasi kaidah ini adalah apabila ada seseorang sedang makan sahur dan dia ragu apakah matahari sudah terbit atau belum maka puasanya sah (Zaidan, 2008).

Kaidah keyakinan tidak dapat dihilangkan oleh kebimbangan memiliki beberapa kaidah turunan yang senada. Salah satu sub-kaidah senada yang sering muncul dalam Fatwa Majelis Ulama Indonesia adalah hukum asal segala sesuatu adalah boleh. Kaidah ini muncul hampir di semua Fatwa DSNMUI terkait perbankan syariah, IKNB, dan pasar modal. Kehidupan akan terus mengalami perubahan. Itulah mengapa terdapat asas hukum yang menyatakan bahwa hukum selalu tertinggal dengan keadaan (Het recht hinkt achter de faiten aan) (Mertokusumo, 2005). Hukum Islam telah mengantisipasi hal ini dengan memberikan payung hukum melalui kaidah yang bernama al-ashlu al-ibahah (Zubair, 2017). Bahwa segala sesuatu memiliki hukum asal halal atau mubah atau ibahah selama belum ada dalil yang mengharamkan (Zubair, 2017). Bidang muamalah dalam masyarakat Islam sering kali berkembang sesuai perkembangan zaman.

c. Kesulitan akan Mendorong Kemudahan

Kaidah ini menerangkan bahwa kesulitan akan datang bersamaan dengan kemudahan. Contohnya adalah apabila terdapat seseorang yang sakit, ia dapat melaksanakan sholat dengan cara duduk bahkan berbaring (Zaidan, 2008). Akan tetapi, tetap terdapat takaran untuk kesulitan yang dimaksud dalam kaidah fiqih ini. Kriteria kesulitan yang dianggap oleh para fuqaha adalah kesulitan yang datang dari sebab perjalanan jauh, sakit, pemaksaan, lupa, ketidaktahuan, kesulitan, keadaan bahaya, dan cacat (Zaidan, 2008).

Ilustrasi penggunaan kaidah ini misalnya peraturan perundangan terkait Perbankan/Perbankan Syariah banyak memberikan kemudahan dalam pemberian layanan syariah melalui Unit Usaha Syariah/Unit Syariah karena minimnya jaringan kantor LKS. Contoh lain adalah penerapan mekanisme pertama dalam pengalihan hutang yang mengandung bai' al inah yang pada dasarnya dilarang (Mulyawisdawati \& Afif, 2018).

\section{d. Bahaya Harus Dihilangkan}

Kaidah ini menekankan pada kata "bahaya". Hal ini dikarenakan, Islam menganggap bahaya adalah sebuah keadaan yang merugikan orang lain (Zaidan, 2008). Itulah mengapa, bahaya harus dihilangkan. Selain itu, Islam juga mengajarkan bahwa menzalimi orang lain adalah haram hukumnya. Salah satu penerapan kaidah ini adalah khiyar atau pembeli dapat mengembalikan barang apabila ditemukan kecacatan pada barang yang dibelinya (Zaidan, 2008).

Kaidah ini sering dimunculkan dalam fatwa DSN-MUI untuk melindungi kepentingan para pihak. Misalnya Fatwa DSN-MUI No: 
12/DSN-MUI/IV/2000 tentang Hawalah dan Fatwa DSN-MUI No : 11/DSNMUI/IV/2000 tentang Kafalah. Berikut adalah kaidah-kaidah senada dengan bahaya harus dihilangkan: bahaya harus ditolak semampu mungkin, kondisi darurat akan memperbolehkan sesuatu yang semula dilarang, sesuai yang diperbolehkan karena kondisi darurat harus disesuaikan dengan kadar daruratnya, bahaya tidak dapat dihilangkan dengan bahaya lain, mencegah bahaya lebih utama daripada menarik datangnya kebaikan. Bahaya khusus harus ditempuh untuk menolak bahaya umum, keadaan darurat tidak membatalkan hak orang lain, kebutuhan terkadang disetarakan dengan kondisi darurat, baik kebutuhan umum maupun khusus (Zubair, 2017).

\section{e. Adat Istiadat Dapat Dijadikan Pijakan Hukum}

Adat istiadat atau tradisi merupakan kebiasaan yang dilakukan secara berulang-ulang (Mertokusumo, 2005), hal ini menyebabkan adat istiadat dapat dijadikan sumber dalam Hukum Islam (Zaidan, 2008). Akan tetapi, dengan catatan tidak adanya nash yang mengatur permasalahan tersebut. Syarat-syarat bagi adat istiadat yang dapat dijadikan hukum adalah sesuatu yang memang sudah berlaku sering dan umum di dalam daerah tersebut sehingga tidak ada satu orangpun yang mempertentangkannya dan tidak bertentangan dengan syariat islam, kemudian syarat kedua adalah tradisi hanya dijadikan perbandingan untuk meruntut kebiasaan yang sudah ada sebelumnya (Zaidan, 2008). Contoh dalam keuangan syariah adalah dibolehkannya akad salam sebagai varian dari jual beli.

Berdasarkan pada paparan mengenai substansi fatwa DSN-MUI, arti penting peran KPJKS, aturan yang berlaku bagi proses transformasi fatwa ke dalam regulasi, metode istinbat hukum ekonomi Islam, dan prinsip hukum dan kaidah fiqih dalam Hukum Islam. Berikut peneliti kemukakan khusus mengenai penggunaan prinsip hukum dan kaidah fikih dalam interpretasi dan harmonisasi fatwa ke dalam regulasi. Mendasarkan pada asumsi hukum bahwa metode istinbat DSN-MUI dan KPJKS adalah sama, maka dengan mengetahui metode pemberian fatwa oleh DSN-MUI juga berarti mengetahui metode yang digunakan oleh KPJKS dalam memberikan rekomendasi atas substansi fatwa sebelum menjadi materi muatan regulasi.

Penggunaan 5 kaidah umum sebelumnya, juga menunjukkan keberadaan teori kemaslahatan yang digunakan dalam transformasi Fatwa DSN-MUI ke dalam regulasi keuangan syariah. Teori kemaslahatan adalah teori yang mengatur bahwa sesuatu yang mendatangkan maslahat/kemanfaatan lebih besar akan didahulukan dari maslahat yang hanya memberikan kemanfaatan bagi segelintir orang (Amri, 2018). Itulah kenapa dalam membuat suatu fatwa, DSN-MUI tidak terlepas dari kaidah-kaidah fiqih yang di dalamnya selalu mengutamakan kemaslahatan bagi banyak orang.

Metode penetapan fatwa DSN adalah mengikuti pedoman atau panduan yang telah ditetapkan oleh komisi fatwa MUI. Adapun pedoman fatwa MUI tertuang dalam Surat Keputusan Majelis Ulama Indonesia No. U596/MUI/X/1997 (Mubarok, 2002). Dalam Surat Keputusan ini terdapat 3 (tiga) bagian proses utama dalam menentukan fatwa, yaitu dasar-dasar umum penetapan fatwa, prosedur penetapan fatwa, serta teknik dan kewenangan organisasi dalam penetapan fatwa. Dasar-dasar umum penetapan fatwa MUI ditetapkan dalam Pasal 2 ayat (1) dan (2). Dalam ayat (1) disebutkan bahwa setiap fatwa didasarkan pada adillat al-ahkam yang paling kuat dan membawa kemaslahatan bagi umat. Kemudian dalam ayat (2) disebutkan bahwa dasar-dasar fatwa adalah al-Quran, Hadis, Ijmak, Qiyas, dan dalildalil hukum lainnya. 
Kewenangan MUI adalah berfatwa tentang hal-hal sebagai berikut: (a) Masalahmasalah keagamaan yang bersifat umum dan menyangkut umat Islam Indonesia secara nasional, dan (b) Masalah-masalah keagamaan di suatu daerah yang diduga dapat memperluas ke daerah lain. (Pasal 10 Keputusan Majelis Ulama Indonesia No. U596/MUI/X/1997) Teknik berfatwa yang dilakukan oleh MUI adalah rapat komisi dengan menghadirkan ahli yang diperlukan dalam membahas suatu permasalahan yang akat difatwakan (Mubarok, 2002).

Menurut Kanny Hidaya, bahwa dalam pembuatan fatwa, DSN menggunakan empat sumber hukum yang disepakati oleh para ulama Sunni, yakni al-Quran, al-Hadis, Ijmak, dan Qiyas. Selain itu DSN juga sering menggunakan salah satu sumber hukum yang diperselisihkan, yaitu: Istihsan, Maslahah Mursalah, Istishab, Sadd alZariah, Urf, Mazhab Sahabi, dan Shar'i Man Qablana (Umam, 2012).

Semua pendapat dari para ulama yang terwadahi di DSN akan didengarkan. Apabila dalam pleno terdapat perbedaan atau dengan kata lain tidak terdapat permufakatan bulat, maka fatwa akan diputuskan melalui mekanisme voting. Dengan voting ini apabila hanya sedikit yang tidak setuju, maka fatwa tetap akan dikeluarkan sepanjang tidak mengandung mafsadat di dalamnya (Umam, 2012).

Apabila dicermati latar belakang fatwa baik dalam bidang Perbankan Syariah, Pasar Modal Syariah, dan IKNB Syariah pada dasarnya sama, yaitu untuk memenuhi kebutuhan masyarakat yang terus berkembang akan tetapi beberapa kegiatan tersebut tidak semuanya dapat dibenarkan dalam Hukum Islam.

Perumusan fatwa di samping harus mendasarkan pada prinsip kemaslahatan sebagai inti dari diturunkannya syariah dan metode istinbat, juga dapat dilakukan dengan mengacu pada kaidah-kaidah fikih. Kaidah fikih yang dipakai dalam merumuskan fatwa tersebut yang tertuang secara eksplisit dalam fatwa DSN-MUI di bidang perbankan syariah, pasar modal syariah, dan IKNB Syariah, yakni tiga kaidah besar (kubra) berupa bahaya harus dihilangkan, kesulitan membahwa kepada kemudahan, dan adat istiadat yang baik dapat dijadikan pijakan hukum (al-adatu muhakamah).

Guna memperoleh sebuah rekomendasi KPJKS yang kuat, selain mendasarkan pada prinsip dan kaidah dalam hukum Islam sebagai dimaksud, maka perlu diperhatikan prinsip atau asas dalam pembentukan peraturan perundang-undangan sebagaimana tertuang dalam Pasal 5 Undang-Undang Nomor 12 Tahun 2011 tentang Pembentukan Peraturan Perundang-Undangan. Artinya OJK sebagai lembaga pengatur di sektor jasa keuangan disarankan untuk memperhatikan dan sekaligus menjadikan rekomendasi tersebut sebagai bahan untuk pembuatan POJK/SEOJK bila rekomendasi yang diberikan secara objektif juga memenuhi asas dapat dilaksanakan, asas kedayagunaan dan kehasilgunaan, serta asas kejelasan rumusan. Isu hukum, isu syariah, dan isu operasional yang ada diharapkan dapat diharmoniskan oleh KPJKS dengan mendasarkan pada prinsip, asas, kaidah yang ada dalam hukum Islam maupun hukum nasional, sehingga mampu menghasilkan rekomendasi yang kuat dan kompatibel bagi praktik Lembaga Keuangan Syariah, namun tetap sesuai dengan Prinsip Syariah.

\section{Simpulan dan Saran}

Peran KPJKS dalam melakukan interpretasi dan harmonisasi fatwa DSNMUI bagi pembentukan POJK di bidang keuangan syariah, yakni memberikan rekomendasi bagi OJK atas hasil penelaahan fatwa DSN-MUI. Pembahasan terhadap suatu fatwa dilakukan melalui forum Working Group Perbankan Syariah (WGPS) yang melibatkan multistakeholders, yakni OJK, DSN-MUI, Mahkamah Agung RI, DSAS-IAI, dan KPJKS. Guna memastikan adanya linearitas antara fatwa dan regulasi keuangan syariah, maka dilakukan konsultasi timbal balik dalam proses penyusunan fatwa dan regulasi dimaksud melalui forum WGPS. Prinsip hukum yang 
dijadikan sebagai dasar bagi realisasi peran dimaksud guna menghasilkan rekomendasi yang kuat dan kompatibel bagi praktik lembaga keuangan syariah, namun tetap sesuai dengan prinsip syariah, yakni prinsip kemaslahatan. Sejak penyusunan fatwa hingga penuangannya ke dalam regulasi DSN-MUI mendasarkan pada metode istinbat hukum dan kaidah-kaidah fikih, yakni berupa: (1) kaidah bahaya harus dihilangkan; (2) hukum asal sesuatu adalah boleh; (3) kesulitan akan mendatangkan kemudahan; dan (4) adat istiadat dapat dijadikan pijakan hukum. Guna menghasilkan rekomendasi yang kuat disarankan bagi OJK dan KPJKS sebagai bagian dari OJK untuk memperhatikan asas dalam pembentukan peraturan perundangundangan, khususnya asas dapat dilaksanakan, asas kedayagunaan dan kehasilgunaan, serta asas kejelasan rumusan.

\section{DAFTAR PUSTAKA}

Alfarouq, A. R. Z. (2018). Positivisasi Fatwa Dewan Syariah Nasional Majelis Ulama Indonesia (DSN-MUI) Tentang Mudarabah Dalam Regulasi Otoritas Jasa Keuangan (OJK). Universtas Islam Negeri Syarif Hidayatullah.

Ali, M. D. (2000). Hukum Islam: Pengantar Ilmu dan Tata Hukum Islam di Indonesia. Jakarta: PT RajaGrafindo.

Amri, M. (2018). Konsep Maslahat dalam Penetapan Hukum Islam (Telaah Kritis Pemikiran Hukum Islam Najamuddin At- ThuFi). Et-Tijarie, 5(2).

Auda, J. (2007). Maqasid al-Shariah as Philosophy of Islamic Law. London: The International Institute of Islamic Thought.

Bahri, S. (2011). Penerapan Kaidah-Kaidah Hukum Islam dalam Istinbath Hukum (Analisis Kajian Dewan Hisbah/Persis). Kanun Jurnal Ilmu Hukum, Th.XIII(55).

Fauzan, A. (2016). Pola dan Urgensi Positivisasi Fatwa-fatwa DSN-MUI
Tentang Perbankan Syariah di Indonesia. Al-Manahij, X(2).

Hammam. (2017). Urgensi Kaidah Fiqhiyyah dalam Perumusan hukum dan Implementasinya dalam fatwa DSNMUI. Et-Tijarie, 4(1).

Iqbal, M. (2018). Urgensi Kadiah-Kaidah Fikih Terhadap Reaktualisasi Hukum Islam Kontemporer. Jurnal EduTech, $4(2)$.

Kalsum, U. (2018). Otoritas Pengawasan Perbankan Syariah Di Indonesia. $\mathrm{Li}$ Falah Jurnal Studi Ekonomi Dan Bisnis Islam, 3(2).

Kusroni. (2019). Mengenal Ragam Pendekatan, Metode, dan Corak dalam Penafsiran Al-Quran. Jurnal Kaca Jurusan Ushuluddin STAI Al Fithrah, 9(1).

Marzuki, P. M. (2005). Penelitian Hukum. Jakarta: Kencana.

Mas, M. (2004). Pengantar Ilmu Hukum. Bogor: Ghalia Indonesia.

Mertokusumo, S. (2003). Mengenal Hukum: Suatu Pengantar. Yogyakarta: Liberty Press.

Mertokusumo, S. (2005). Mengenal Hukum: Suatu Pengantar (2nd ed.). Yogyakarta: Liberty.

Mubarok, J. (2002). Metodologi Ijtihad Hukum Islam. Yogyakarta: UII Press.

Mulyawisdawati, R. A., \& Afif, M. (2018). Jual Beli Model 'Inah di Lembaga Keuangan Syariah: Tinjauan Konsep, Hukum dan Implementasi. FALAH Jurnal Ekonomi Syariah, 3(1).

Soekanto, S. (1986). Pengantar Penelitian Hukum. Jakarta: Universitas Indonesia Press.

Tim Penyusun Materi Pengembangan Keuangan Syariah 2014. (2014). Laporan Perkembangan Keuangan Syariah 2013. Jakarta. 
Tim Penyusun Materi Pengembangan Keuangan Syariah 2015. (2015). Laporan Perkembangan Keuangan Syariah 2014. Jakarta.

Tim Penyusun Materi Pengembangan Keuangan Syariah 2016. (2016). Laporan Perkembangan Keuangan Syariah 2015. Jakarta.

Tim Penyusun Materi Pengembangan Keuangan Syariah 2017. (2017). Laporan Perkembangan Keuangan Syariah 2016. Jakarta.

Tim Penyusun Materi Pengembangan Keuangan Syariah 2018. (2018). Laporan Perkembangan Keuangan Syariah 2017. Jakarta.
Umam, K. (2012). Legislasi Fikih Ekonomi Perbankan: Sinkronisasi Peran DSNMUI dan Komite Perbankan Syariah. Mimbar Hukum, 24(2).

Zahrah, M. A. (2018). Ushul Fiqih (M. Azhari, Ed.). Jakarta: Pustaka Firdaus.

Zaidan, A. K. (2008). Al-Wajiz 100 Kaidah Fikih dalam Kehidupan Sehari-hari (Y. Maqosid, Ed.). Jakarta: Pustaka AlKautsar.

Zubair, M. (2017). Formulasi Nalar Fiqh Telaah Kaidah Fiqh Konseptual Buku Satu (VI; Syahrowardi \& A. Sailani, Eds.). Surabaya: Khalista. 